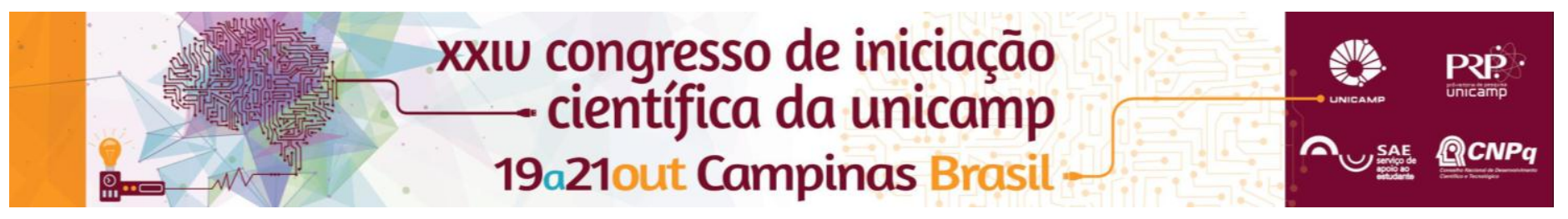

\title{
Intuição e intelecto na pintura de Wassily Kandinsky: os anos da Bauhaus
}

\section{Débora Brombal Visnadi (IC)}

\section{Resumo}

Esta pesquisa estuda a produção abstrata do artista russo Wassily Kandinsky, analisando-a a partir do surgimento do componente geométrico em sua obra e sua consequente evolução, com enfoque na máxima do uso de tais elementos formais na época em que o artista lecionava na escola alemã de design e arquitetura Bauhaus.

\section{Palavras-chave:}

Wassily Kandinsky, Bauhaus, pintura abstrata

\section{Introdução}

Apoiando-se nos escritos do próprio artista - que atuavam como verdadeiros tratados da cor e da forma a pesquisa visa evidenciar as relações entre o espírito ao mesmo tempo apolíneo e dionisíaco que permeia a produção teórico-artística do pintor. Ainda que acusado pelos críticos de produzir uma arte fria e intelectual quando começou a mostrar uma tendência à geometrização, defendia acima de tudo "a ressonância espiritual, a ação direta da cor sobre a alma". A pesquisa analisa de forma mais desenvolvida os elementos compositivos da pintura de Kandinsky durante os anos de 1925 a 1933, delimitando o período em que a geometrização do pintor se mostrou de forma mais estrita e em maior escala, bem como o período em que se demonstrou sua maior maturidade teórica.

\section{Resultados e Discussão}

A relação de Kandinsky com a música é um dos pilares para a compreensão de sua trajetória: segundo ele, por esta ser uma forma de arte essencialmente abstrata, a "mais imaterial de todas", e não imitativa, sempre foi a maior entre elas a conseguir uma aproximação com a alma.

Em seu livro Do Espiritual na Arte, publicado em 1912, Kandinsky afirma recusar a arte somente decorativa, buscando a ressonância espiritual da cor. Para tal, ele associa a vibração interna de cada cor à dos sons emitidos pelos diferentes instrumentos musicais: "o azulclaro assemelha-se à flauta, o azul-escuro ao violoncelo e, escurecendo cada vez mais, lembra a sonoridade macia de um contrabaixo"1, por exemplo.

De acordo com o pintor, o amarelo é uma cor excêntrica, tende a se expandir; e considera o azul seu oposto, uma cor concêntrica, tendendo ao interior e sendo, por este motivo, a cor mais espiritual dentre as demais. A oposição entre azul e amarelo é a base de sua teoria da cor, tendo no verde seu ponto de equilíbrio, uma vez que afirma que os movimentos excêntricos e concêntricos se anulam, mantendo o repouso.

Com a publicação de Ponto e linha sobre o plano em 1926, Kandinsky também apresenta seus pensamentos a respeito das formas e suas ressonâncias internas, complementando o lançamento anterior. Seus estudos mais aprofundados sobre as formas têm início quando o artista retorna ao seu país de origem por alguns anos, entre o período expressionista e o da Bauhaus, quando entra em contato com as vanguardas russas. Nessa época, começa a incorporar alguns elementos geométricos em sua pintura, que se desenvolveriam ainda mais na escola alemã de arquitetura e o levariam à publicação do mencionado título.

Como o enfoque da investigação é o de uma geometria mais estrita, foram assinaladas cinco obras para estudo e análise mais aprofundada: Acento em rosa (1926), Vários círculos (1926), Oito vezes (1929), Diagonal (1930) e Treze retângulos (1930).

\section{Conclusões}

Para Kandinsky, na arte, a teoria nunca precede a prática. No conjunto de sua obra, é possível notar a combinação dos elementos formais aqui apresentados desde antes da publicação de seus livros, e uma posterior intensificação dos estudos pictóricos como forma de adquirir as ressonâncias espirituais desejadas, utilizando-se para tal a temática geométrica.

Artista de gênio ao mesmo tempo apolíneo e dionisíaco, sua arte - ainda que considerada fria e intelectual por alguns críticos da época - ao adotar uma tendência à geometrização, é, pelo contrário, contra a razão pura, sendo dotada de uma capacidade de síntese entre questões da intuição e do intelecto na universo da pintura.

\section{Agradecimentos}

Agradeço à minha orientadora, $\operatorname{Prof}^{-a} \operatorname{Dr}^{\mathrm{a}}$ Maria de Fátima Morethy Couto, pelo apoio e direcionamento durante a evolução dos estudos. Agradeço ao $\mathrm{PIBIC/CNPq}$ pela oportunidade da realização do projeto, e também a todos que fizeram parte deste ano de pesquisas, de forma direta ou através de contínuos incentivos.

${ }^{1}$ KANDINSKY, Wassily. Do espiritual na arte e na pintura em particular. São Paulo: Martins Fontes, 1996. 